\title{
Survey of the terrestrial habitats and vegetation of Shetland, 1974 - a framework for long-term ecological monitoring
}

\author{
Claire M. Wood ${ }^{1}$ and Robert G. H. Bunce ${ }^{2}$ \\ ${ }^{1}$ Centre for Ecology and Hydrology, Lancaster Environment Centre, Bailrigg, Lancaster, LA1 4AP, UK \\ ${ }^{2}$ Estonian University of Life Sciences, Kreuzwaldi 5, 51014 Tartu, Estonia \\ Correspondence to: Claire M. Wood (clamw@ceh.ac.uk)
}

Received: 12 October 2015 - Published in Earth Syst. Sci. Data Discuss.: 23 October 2015

Revised: 3 February 2016 - Accepted: 14 February 2016 - Published: 25 February 2016

\begin{abstract}
A survey of the natural environment was undertaken in Shetland in 1974, after concern was expressed that large-scale development from the new oil industry could threaten the natural features of the islands. A framework was constructed by the Institute of Terrestrial Ecology on which to select samples for the survey. The vegetation and habitat data that were collected, along with the sampling framework, have recently been made public via the following doi:10.5285/06fc0b8c-cc4a-4ea8-b4be-f8bd7ee25342 (Terrestrial habitat, vegetation and soil data from Shetland, 1974) and doi:10.5285/f1b3179e-b446-473d-a5fb-4166668da146 (Land Classification of Shetland 1974). In addition to providing valuable information about the state of the natural environment of Shetland, the repeatable and statistically robust methods developed in the survey were used to underpin the Countryside Survey, Great Britain's national long-term integrated environmental monitoring programme. The demonstration of the effectiveness of the methodology indicates that a repeat of the Shetland survey would yield statistics about ecological changes in the islands, such as those arising from the impacts of the oil industry, a range of socio-economic impacts, and perhaps climate change. Currently no such figures are available, although there is much information on the sociological impacts, as well as changes in agriculture.
\end{abstract}

\section{Introduction}

In the 1960s, the discovery of North Sea oil off the coast of Shetland, Scotland, meant that the islands had to face the prospect of large-scale development to accommodate the infrastructure surrounding the industry. In the early 1970s, concern was expressed by the county council that such development would threaten the natural features of Shetland, such as landscape and wildlife. Accordingly, in 1974, a survey was commissioned by the Nature Conservancy Council (now Scottish Natural Heritage in Scotland) and organised by the Institute of Terrestrial Ecology (ITE) (now part of the Centre for Ecology and Hydrology) to assess the natural environment of the islands. Although the terrestrial habitats and vegetation survey are the focus of this paper, assessments of freshwater and littoral habitats, sea-bird populations, geology and geomorphology were also undertaken around the same time as part of a larger integrated survey (Milner, 1975).

The specific objectives of the terrestrial component were as follows:

i. To assess the range of variation within the vegetation of Shetland and to provide a user guide to defined types.

ii. To provide a structural basis for monitoring future change in the vegetation (Bunce, 1975).

The Shetland Survey was also a stage in the development by ITE of the methodology of strategic ecological survey, as described by Sheail and Bunce (2003).

The vegetation survey was undertaken using standardised methods outlined by Bunce and Shaw (Bunce and Shaw, 1973; Bunce, 1974). In order to randomly sample Shetland in a strategic way, the islands were stratified into a set of 16 
relatively homogenous areas (strata, or "land classes"). Sampling locations were randomly selected from within each of these strata, giving a total of eighty $1 \mathrm{~km}^{2}$ sampling units, each containing up to $16200 \mathrm{~m}^{2}$ sampling plots. Records of plant species, soils, habitat types and major biota present were collected.

Prior to the survey, a two-day training course was held to familiarise the surveyors with the detailed field protocols. Additionally, all survey teams were initially accompanied by a supervisor, and regular visits into the field were made by the project leader to ensure consistency and quality in data recording according to criteria laid out in the field handbook (Bunce, 1974).

At the time, the statistical sampling methods used were generally not widely used as a method for ecological monitoring, and this was one reason why the results were not reported publicly at the time. The other factor was that the senior author also had other commitments. Therefore, this is the first time that the data and results have been made widely available. There have been many changes in the islands since the survey, both socio-economic and environmental, and the data provide a unique opportunity to explore the changes that have taken place in the vegetation, should a repeat survey be undertaken.

In addition to the survey yielding an interesting set of data in itself, the methodological framework for the survey eventually developed into the largest long-term ecological monitoring project in Britain, the Countryside Survey (CS) (Carey et al., 2008). CS started in 1978 and was most recently undertaken in 2007.

\section{Shetland}

The Shetland Islands cover an area of about $1400 \mathrm{~km}^{2}$ and consist of over a hundred islands and islets, of which about 15 are inhabited. The southernmost tip of the largest island lies over $160 \mathrm{~km}$ north-west of John o' Groats. Lying at the northern limit of the Britain, the isles have considerable biogeographic interest.

The islands are geologically diverse, with the main rock types being metamorphic, including Caledonian schists, gneisses and quartzites. There are also areas of Old Red Sandstone.

The inland topography is gentle, with wide, shallow valleys. Around the coast, there are sheer cliffs, and numerous sheltered inlets or "voes". There are few trees on the islands, and extensive areas are covered in peat, especially on the Mainland and the northern island of Yell. The soils on Shetland are generally poor, with the most fertile land being on the sandstone in the south, where the main crofting districts are located.

The general climate is mild, moist and windy. Although minor changes may be discerned over time (see Sect. 3.3), there is little variation in temperature through the year, with the average monthly temperature ranging from approximately $3{ }^{\circ} \mathrm{C}$ (February) to $12^{\circ} \mathrm{C}$ (July) (Met Office, 2015). The exposed situation of the islands means they are subject to high winds, with about 40 days of gales per year. The rainfall is not extreme (around $1124 \mathrm{~mm}$ per annum) (Met Office, 2015) but is distributed throughout the year, so that damp and drizzly days are common.

\section{The survey in context}

The survey of Shetland is relevant on a number of levels. Firstly, the data are of local interest to anyone concerned with the ecology and land use of the islands. Should a resurvey be undertaken, potential changes in vegetation could be assessed against a range of local and national socio-economic changes occurring since the 1970s. Secondly, the data are of a wider global significance when applied to the potential effects of global climate change.

Additionally, as described in Sect. 4, the design of the methodology itself is of importance, having been applied to national monitoring schemes in Britain, and beyond.

\subsection{The survey in a local context}

At the time of the survey, a review of the available ecological knowledge regarding Shetland was made by Goode (1974). Attention was drawn to the major gaps that were present, few of which have since been filled. Insufficient information and detail were available on the islands in McVean and Ratcliffe (1962). Birse (1974) provided a general account of Sullom Voe and Barkham (1971) and Allot (1971) described aspects of Foula. The specialised habitats of the fell fields and the serpentine are also summarised by Spence (1974). Most of the published work has concentrated on two specialised habitats - the Fell fields of Ronas Hill and the serpentine habitats of Unst (Spence, 1974). The small areas of relict scrub, mainly on ungrazed islands in the lochs, are also described by the same author.

The only major paper on the overall vegetation is by Roper-Lindsay and Say (1986), who used phytosociological methods to describe 17 associations in relation to British, continental and Scandinavian communities. They found difficulties in determining discrete associations because of factors such as intensive land use and the maritime influence. Hence, the present study is the first to provide a complete overview of the vegetation of the islands.

By contrast, the flora of Shetland is relatively well known, for example Scott and Palmer (1987) for vascular plants and Dalby and Dalby (2005) for lichens and as summarised in the BSBI Atlas of the British and Irish Flora (Preston et al., 2002), which is due to be updated in 2020, and the original bryophyte atlas published in 1991-1994 (Hill et al., 1991) but recently repeated (Blockeel et al., 2014). Also, Hill and Paton (1976) have reported on the saxicolous bryophytes. The phyto-geographic relationships of the Shetland flora have 
been widely discussed, as summarised by Goode (1974). Although some species differ in their ecology because of the northern location, the species complement is closely related to that of northern Scotland. Recent overviews of the ecology of the islands are given by Berry and Johnston (1980) and Johnston (1999).

Superficially, the vegetation is similar to northern Scotland except for the extensive maritime influence and the distinctive vegetation on the serpentine, which is similar to that of comparable outcrops elsewhere, for example on Rhum in western Scotland. Although at a lower altitude than in northern Scotland, the sub-arctic vegetation on Ronas Hill is otherwise similar to high altitudes on other Scottish mountains.

In order to obtain a general comparison with the environment and land cover of Shetland with the rest of Britain, data from Britain's national monitoring programme, the Countryside Survey (Brown et al., 2014), may be used. The overall land cover, described by the CS survey data, is dominated by bogs and acid grassland habitats and provides an independent comparison with the results from the vegetation survey described below. In terms of a general comparison of the environmental characteristics of Shetland with the Outer Hebrides and Orkney using the environmental classes of the ITE Land Classification (Bunce et al., 2007), the former is shown to indeed be an outlier and is dominated by the most pronounced overall land class -32 . Class 32 can be summarised as having variable topography, mainly at medium/low altitudes, peaty soils, peatland and moorland vegetation types, and a landscape of scattered lochs and eroding peat hags (Benefield and Bunce, 1982). All the other classes in the islands, except one, a marginal upland class, are also upland, showing that Shetland is upland in its affinities even though it has no land at high elevations.

\subsection{Drivers of potential change - socio-economic factors}

Overall, Shetland has undergone a range of changes since the 1970s, largely driven by economic and political factors, most notably the new oil industry. Wills (1991) provides a thorough account of the overall impact of the new Shetland oil industry, describing how the new multi-million-pound terminal at Sullom Voe had major impacts on the traditional culture, economy and environment of the islands. The conflict between economic growth and biodiversity conservation has often been discussed (for example in Chambers et al., 2014; Czech, 2003), and in the case of smaller island communities, the introduction of economic growth tends to have an even greater impact on the environment than might be the case elsewhere (Daly and Farley, 2011). Examples of this have been explored in islands around the world, for example in Sakhalin, Russia (Wilson, 2003), and most recently in the Caribbean (Huettmann, 2015).

In Shetland, there has been a general decline in traditional crofting agriculture, partly due to the availability of well-paid jobs in the oil industry, and factors such as EU subsidies. Key habitats and species of conservation value are often found in crofting communities; therefore these are now under threat (Scottish Rural Development Programme, 2016). Additionally, the demography of the crofting community is changing and many common grazings now have insufficient active adults to undertake routine operations such as sheep roundups. This has seen fairly widespread apportionment (fencing of hill shares) which has broken up large hill units.

Sheep numbers have fluctuated in response to headage subsidies from the EU, from around 265000 in 1971 to nearly 400000 in 2001 (Scottish Government, 2016), with the associated grazing pressures. This figure reduced to around 280000 in 2010 as a result of subsidies switching to area payments in the early 2000s and agri-environment schemes encouraging better stewardship of the land. Additionally, the amount of land put to silage has increased markedly since the 1970s, whilst at the same time the amount of arable has dropped (Scottish Government, 2016),

The availability of grant aid from the Local Authority (as a result of oil income) meant that there was a considerable amount of re-seeding, surface seeding or liming of moorland/heathland, as well as large drainage schemes. Now that the economic situation is currently less favourable, there is no money available to crofters for these activities, and much of this improved land is reverting back (Scottish Natural Heritage, 2002).

Peat is frequently used as a domestic fuel in Shetland. Peat cutting has declined, although there has been a small resurgence in recent times, in response to high oil prices. Mechanised cutting can seriously damage blanket bog by draining the peat and destroying large areas of surface vegetation. However, there are now only a few commercial peat cutting operators and the practice is currently viewed as unsustainable (Scottish Natural Heritage, 2002).

The construction of the third largest wind farm in Scotland (Viking Energy, 2016), due to be built in the near future, could also affect the vegetation of this islands by altering the local microclimate.

Sulfur deposition from shipping is also likely to have had a certain impact on the Shetland environment, as well as oil spillages. A notable oil spillage occurred in 1993, when the MV Braer ran aground off the islands, carrying 85000 tonnes of crude oil. The significant and persistent environmental effects of major oil spills such as these is emphasised by Ott (2005) in relation to the 1989 Exxon Valdez spill off Alaska.

\subsection{Drivers of potential change - climate change}

It would be expected that the most significant drivers of changes in the vegetation and habitats would be largely the socio-economic factors described. However, there is also the possibility that climate change may have already had some effect on the Shetland vegetation, and may do so in the future. Changes in the climate since the 1970s have not been great, 


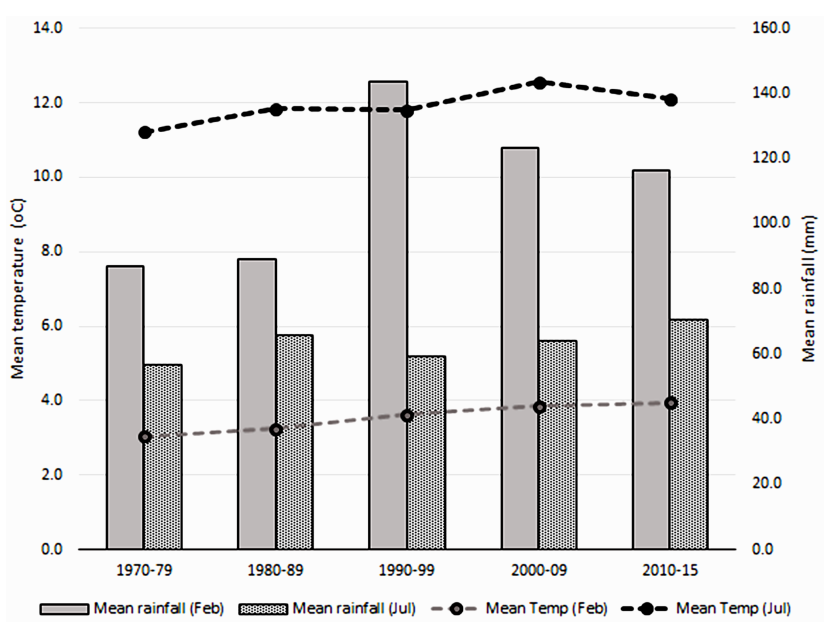

Figure 1. Climate trends in Shetland 1970-2015 (Met Office, 2015).

but from the climate data presented in Fig. 1, there appears to be a trend towards higher temperatures and wetter winters. In the next 50 years, average temperatures are predicted to rise by $0.5-1.5^{\circ} \mathrm{C}$, with $6-13 \%$ more rainfall (Scottish Natural Heritage, 2002).

In a European context, Shetland is located in the Atlantic North zone, as described by Metzger et al. (2008). The Atlantic environment is relatively stable compared to other regions, and is not expected to change dramatically in extent or location in comparison to other zones (Metzger et al., 2008). However, the effects of potential climate change are difficult to predict. The species and habitats most likely to be affected are those which are close to the limits of their range, such as arctic-alpine plants. In Shetland, due to the cool winds, arctic-alpine species are present at much lower altitudes than would be expected on the British mainland. These species include Carex bigelowii and Silene acaulis. A warmer climate would perhaps result in a loss of these arctic-alpines and an increase in more generalist species, such as Agrostis tenuis and Festuca rubra. The Global Observation Research Initiative in Alpine Environments (GLORIA) project has yielded research from the Swiss, Austrian and Italian Alps showing that warming causes arctic-alpine species to retreat to elevations higher than those pre-warming (Grabherr et al., 2010). As Shetland does not have higher elevations, it is likely the arctic-alpine species there would be lost in the event of climate warming. Monitoring these species in the islands would provide an early warning of the effects of climate change. Additionally, as this survey covers a range of functional plant types, changes in these could also be analysed in the context of climate change.

\section{Survey design: site selection and stratification}

The method used to undertake the survey initially requires that an environmental classification of the whole area in question (in this case, Shetland) is constructed using multivariate analysis of environmental characteristics to produce a set of strata, or areas of relatively homogenous regions. These strata can then be used for randomly selecting sample sites in order to sample ecological parameters such as vegetation. By using this statistically robust method, it is then possible to scale up the results from the sample sites to describe the entire population.

By the end of the 1970s, this idea of stratifying the landscape led to the successful creation of a stratification for the whole of Great Britain, known as the "Institute of Terrestrial Ecology (ITE) Land Classification of Great Britain" (Bunce et al., 1990, 1996a, b). Although this has developed over time (Bunce et al., 1998, 2007), the basic stratification still underpins the CS (Carey et al., 2008).

\subsection{Land stratification - "ITE Land Classification of Shetland"}

This "ITE Land Classification of Shetland" (Bunce and Bassett, 2015) separated the $2046 \mathrm{~km}^{2}$ of the grid of the national mapping agency, the Ordnance Survey, into 16 relatively homogeneous units (known as strata, or "land classes") with similar environmental characteristics and geographical features, ascertained from a map study. Most of the criteria were derived from one-inch-to-a-mile (1:63 360) Ordnance Survey maps, with the 18 geological attributes being recorded from the quarter-inch geological map (British Geological Survey, 1963), which was the only one to give complete cover. It was decided to use the $1 \mathrm{~km}$ grid squares as the sampling unit, as these have the advantage of being fixed and readily referable between maps of different scales.

The range of geographical factors on a map can be broadly divided into physical attributes (such as hills, valleys, coastlines) and features of human geography (for example roads and houses), and it was decided from the outset to consider only the physical geography of Shetland in order to provide a classification which would be readily interpretable in terms of landform.

The geographical features fall into two types:

i. Continuous, e.g. altitude and slope, which can be represented as an integer or decimal number.

ii. Attribute data, in which the feature is either present or absent, e.g. a cliff or hill top.

The full list of 150 attributes is given in supporting documentation supplied with the data set (Bunce, 1975).

There are 2046 one-kilometre squares in Shetland containing some land, which were each allocated to one of the 16 strata using indicator species analysis (now TWINSPAN) 
Table 1. Description of strata.

\begin{tabular}{lll}
\hline Group & Strata & Description \\
\hline 1 & Strata 1-4 & $\begin{array}{l}\text { Coastal strata with few rivers running into the sea within the square. There is more than } 80 \% \text { land area, and } \\
\text { terrain is relatively gentle. }\end{array}$ \\
\hline 2 & Strata 5-8 & $\begin{array}{l}\text { Coastal group with more sea and steeper slopes. It is more likely to contain headlands and sea cliffs. There } \\
\text { are also more likely to be more rivers entering the sea. }\end{array}$ \\
\hline 3 & Strata 9-12 & $\begin{array}{l}\text { High altitude inland group with a 600-900 ft (182-274 m) hill within the square or close by. There are few } \\
\text { small water bodies and the major rock is likely to be gneiss. }\end{array}$ \\
\hline 4 & Strata 13-16 & $\begin{array}{l}\text { Lower, more undulating group with much peat and many freshwater lochans. The hills are about 300 ft } \\
(91 \mathrm{~m}) \text { and the rock is more likely to be Old Red Sandstone. }\end{array}$ \\
\hline
\end{tabular}

described in Hill (1973) and Hill et al. (1975) as shown in Figs. 2 and 3. The environmental classes were produced using an arbitrary stopping rule. The first division of the environmental classification was on the basis of inland versus coastal features (Fig. 3). The eight coastal types are distinguished by the different proportions of sea and inlets such as voes. The eight inland classes are based on exposure and drainage patterns. Overall, it was found that the square's relationship with the sea dominated the classification. A summary description of the classes is given in Table 1.

\subsection{Sampling sites and plots}

The sample survey sites were based on $1 \mathrm{~km}^{2}$ units randomly selected from across Shetland, as shown in Fig. 2. Five of these square units were randomly chosen from each of the 16 strata (or land classes) for survey, giving a total of $801 \mathrm{~km}^{2}$ units to be surveyed.

Within each selected $1 \mathrm{~km}^{2}$ unit (or survey site), 16 individual $200 \mathrm{~m}^{2}$ plots were chosen for detailed survey (Fig. 4). In order to allocate the location of these, each of the $80 \mathrm{se}$ lected $1 \mathrm{~km}^{2}$ units was split into 16 equal sub-squares using an overlay grid, and a point location for the $200 \mathrm{~m}^{2}$ plot was then randomly selected from within each of the 16 subsquares. If a sub-square contained no land, that sub-square (and hence plot) was omitted from the survey; therefore, between 1 and 16 plots were surveyed for each of the $1 \mathrm{~km}^{2}$ units. In total, 927 plots of $200 \mathrm{~m}^{2}$ were selected, although only 911 of these plots were actually surveyed as occasionally it was not possible to record the plot due to inaccessibility of a particular piece of land, for example due to a dangerous cliff or cultivated land. The location of each plot was marked on a one-inch-to-a-mile $(1: 63360)$ map.

A key aim of the sampling design was that the methods chosen should be standardised, therefore highly repeatable. The size of the plot was chosen with reference to continental phytosociologists, who at the time most widely used plots of between 100 and $200 \mathrm{~m}^{2}$ (Bunce and Shaw, 1973). After preliminary field tests, it was found that the number of species recorded usually stabilised at this size. The area

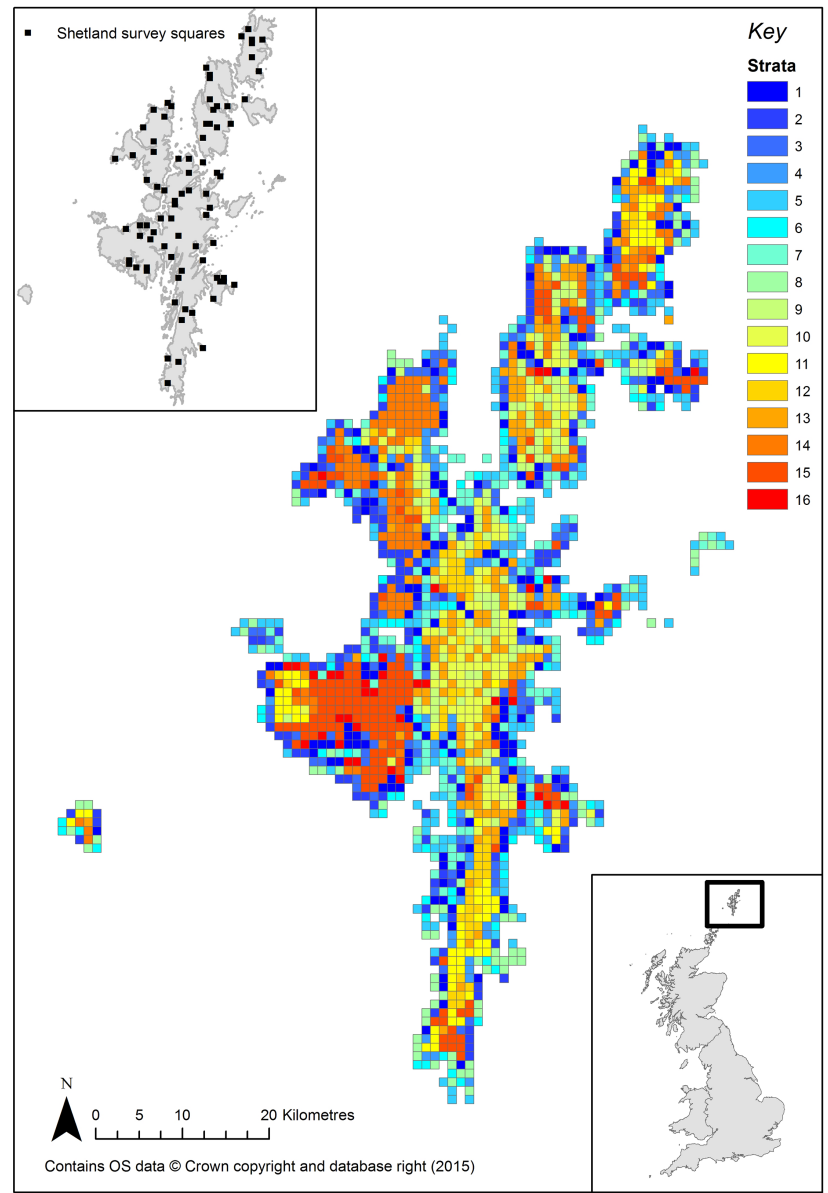

Figure 2. Map of sampling sites and strata.

of $200 \mathrm{~m}^{2}$ was thus adopted for this survey, with five nests within (Fig. 5). This design of plot aids a systematic search of the vegetation within; it is also straightforward to layout in the field, and ensures a standard-sized plot is laid out every time. The plots were constructed as shown in Fig. 6, with one centre post and four corner posts, with a set of four strings tagged with markers at specified distances. The centre post 


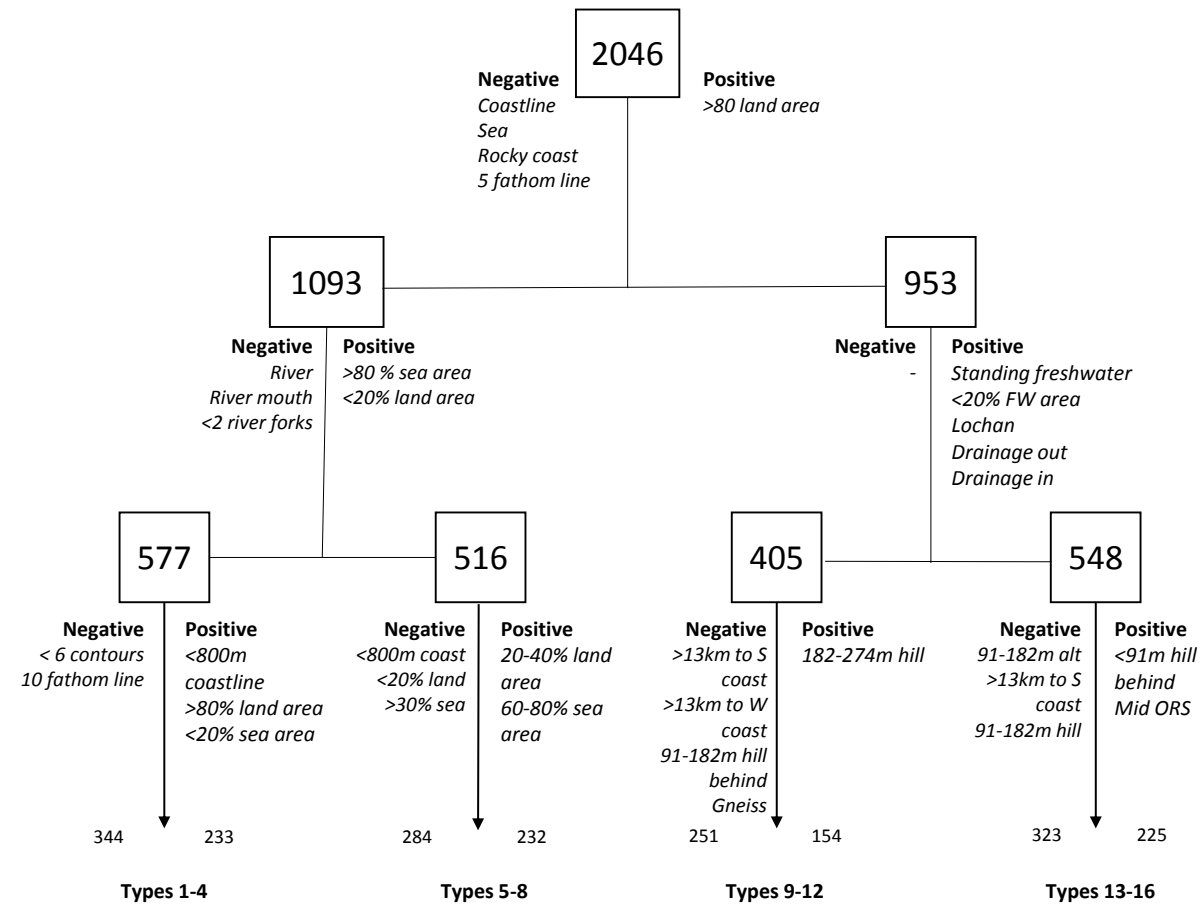

Figure 3. Hierarchy of divisions in the land classification (numbers refer to number of $1 \mathrm{~m}$ grid squares).

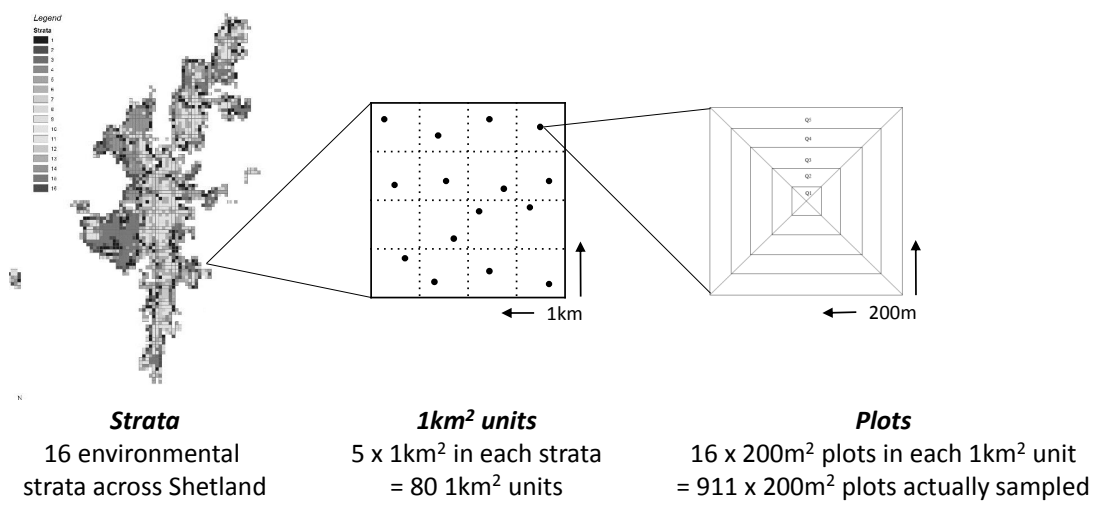

Figure 4. Sampling design.

had a right-angled gauge affixed to the top in order to orientate the plot at random.

In the field, plots were located using the prepared map, and then by pacing from the nearest relocatable feature. It was stressed in the field handbook that there should be no subjective bias in locating the plots on the ground, and the plots in the field should be located as accurately as possible from the map. Data were then collected on ground flora, soils and habitat characteristics for the plot. A habitat sheet for the area within $50 \mathrm{~m}$ of the plot was also compiled.

The sampling intensity of 16 plots per site was originally used in a previous survey, the Woodland Survey of Great Britain in 1971 (Wood et al., 2015), and was chosen on the basis of previous experiences in surveying a wide variety of sites in the north of England and Wales. It also coincided with the time and manpower available (Bunce and Shaw, 1973).

\section{Data collected}

An overview of all the data collected from the survey is given in Table 2. These categories are described in more detail in the following subsections.

\subsection{Site information, plot locations and information, slope and aspect}

For each plot surveyed, both from within the $200 \mathrm{~m}^{2}$ plot and from the surrounding area to within $50 \mathrm{~m}$ of the edge 
Table 2. Summary of data collected.

\begin{tabular}{ll}
\hline Data category & Description \\
\hline Ground flora & Vascular plants, bryophytes and lichens present in the plot \% cover/abundance estimates \\
\hline Plot description and habitats & Tick list of features (broad categories): \\
& - Rock habitats \\
& - Aquatic habitats \\
& - Open habitats \\
& - Vegetation structure \\
& - Animal signs \\
& - Management \\
& - Land use \\
& Tick list description from small pit and augur boring in the centre of the plot - to determine soil type \\
& Composite soil sample from top 10-15 cm taken for pH \\
\hline Soil data & Tick list of features (broad categories) - as for plot, plus adjacent land use and boundary type \\
\hline Within $50 \mathrm{~m}$ of plot description & Slope, aspect \\
\hline
\end{tabular}
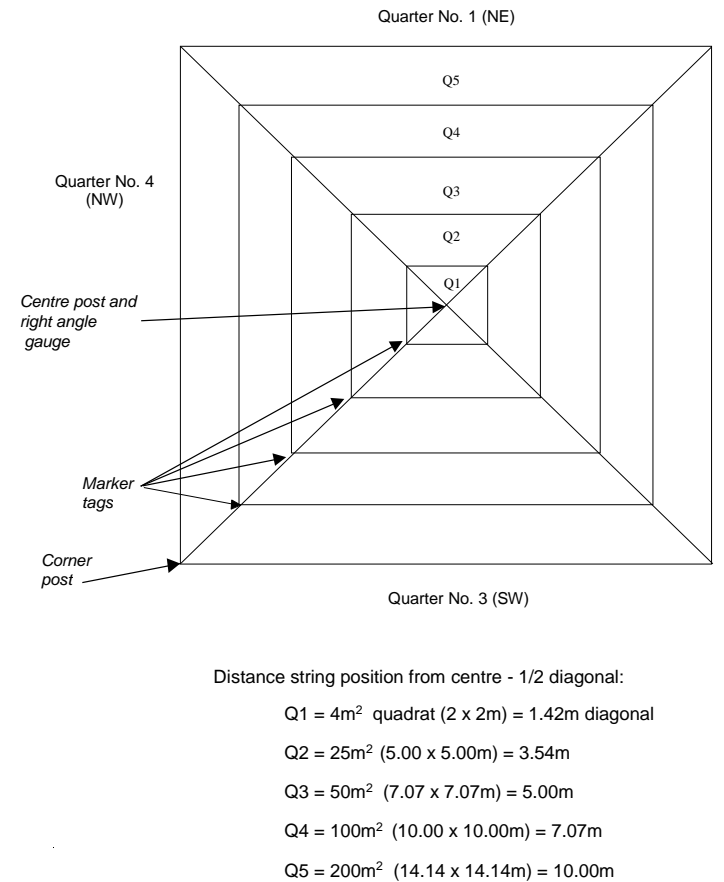

Not to scale

Figure 5. Layout of vegetation plot.

of the plot, the presence and absence of a series of attributes were recorded. Attributes included physical factors such as the presence of rock or cliffs; habitat-related factors such as the presence of heather, bryophytes and trees; aquatic habitats such as ponds; presence of buildings, quarries or rubbish; presence of animals and birds; and also boundary types and nearby land use. All classes within each of the pre-defined habitat categories which were relevant to the survey area were marked off on the appropriate data sheet. Precise def-

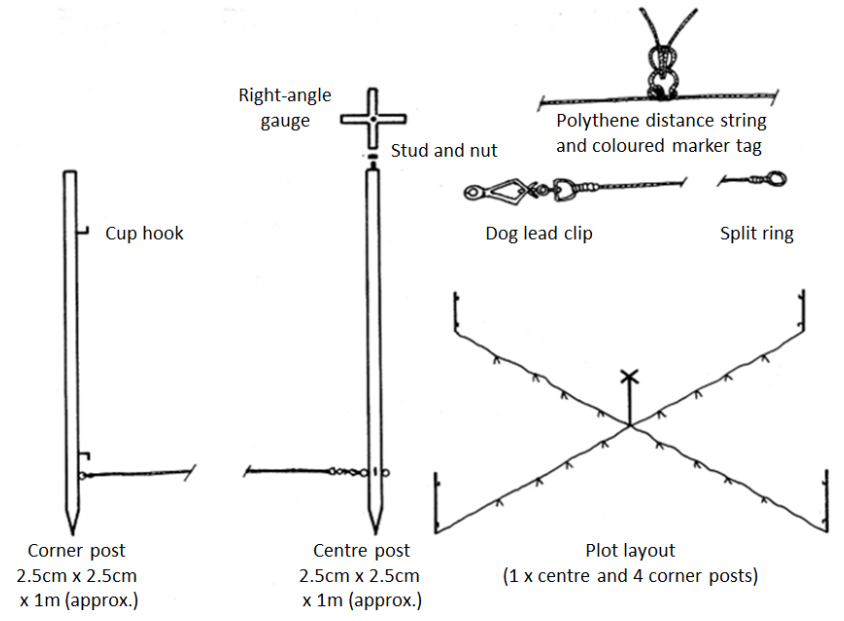

Figure 6. Plot construction.

initions for each habitat category and its classes were provided, and a full list of habitats may be found in the 1974 field handbook (Bunce, 1974) (supplied as supporting documentation with the data sets). The slope of each plot was measured using a clinometer from the highest to lowest point passing through the centre of the plot. The aspect was taken bearing down the slope, measured with a magnetic compass.

\subsection{Vegetation data}

Within the plot described in Fig. 5, the area within the first nest of the plot $(2 \times 2 \mathrm{~m})$ was searched for the presence of all vascular plants (monocots, dicots, gymnosperms and ferns, including tree species) as well as bryophytes and macrolichens growing on soil. This procedure was repeated for each nest of the quadrat, increasing the size each time as shown in Fig. 5. In the final nest (the whole $200 \mathrm{~m}^{2}$ plot), 
the percentage cover (to the nearest $5 \%$ ) of each species was estimated. In addition, the total cover of bryophytes was estimated from the entire plot, as was an overall estimate for litter, wood, rock, bare ground and standing water.

\subsection{Soil data}

The soil of each plot surveyed was classified by horizon using a set of standard categories. In the centre of each plot a shallow pit was dug to enable examination of the surface layers of soil, and auger samples were taken to classify lower horizons. Precise definitions for each of the descriptive categories used and are detailed in the field handbook. A sample from the top $10 \mathrm{~cm}$ was taken away for $\mathrm{pH}$ analysis. A single composite soil sample was taken from each plot, at the centre of the vegetation quadrat, using a trowel. Samples (weighing approximately $1 \mathrm{~kg}$ ) were taken to a depth of $15 \mathrm{~cm}$ and placed in a labelled plastic bag. A pH reading was taken on a representative fresh subsample from each soil sample, using a field $\mathrm{pH}$ meter.

\section{Data quality and repeatability}

During the survey, all survey teams were initially accompanied by a supervisor and regular visits into the field were made by the project leader to ensure consistency and quality in data recording according to criteria laid out in the field handbook (Bunce, 1974).

The data sets were transferred from the original field sheets to spreadsheets in the 2000s. They were checked and corrected to produce a final validated copy. Standard validation checks included plot and site counts to ensure no duplicate numbering and hence double counting of plots; also, range checks were undertaken where possible for values falling within certain ranges, such as soil $\mathrm{pH}$ or slope values.

In terms of the soil data, the descriptive profile data were collected to the standards set out in the training and field handbook, but these were not formally checked for quality aside from checks from supervisors during the survey.

In terms of the representativeness of the plot information across a wider area, an analysis is presented in the survey report (Bunce, 1975). This analysis was undertaken on the Walls Peninsula, an area of Shetland, and compares the results gained from the plot information against information from aerial photographs. The correspondence between the different values was found to be reasonably close at a broad vegetation category level (Table 3 ).

The methodology has subsequently been developed further (for example in CS; Maskell et al., 2008b) to include a habitat mapping component to capture the variation in habitats across $1 \mathrm{~km}$ squares. This could perhaps be usefully incorporated into a repeat survey of Shetland.

In terms of repeatability, it is certainly the case that statistical analyses of temporal vegetation change are more powerful when based on records from plots located in the same
Table 3. Comparison of broad vegetation group covers on the Walls Peninsula: plot estimates versus aerial photography estimates.

\begin{tabular}{lrr}
\hline Group & $\begin{array}{r}\text { Plot } \\
\text { estimate of } \\
\text { cover } \%\end{array}$ & $\begin{array}{r}\text { Aerial } \\
\text { photo estimate } \\
\text { of cover \% }\end{array}$ \\
\hline Calluna/Eriophorum & 29.5 & 39.0 \\
Calluna/Nardus & 23.0 & 25.0 \\
Nardus & 14.9 & 17.0 \\
Juncus effusus & 10.1 & 3.0 \\
Calluna/Rhacomitrium & 5.4 & 10.0 \\
Festuca rubra & 4.7 & 3.0 \\
Agrostis/Holcus & 11.4 & 6.0 \\
\hline
\end{tabular}

place rather than randomised to new locations at each survey. Surveys using exactly the same methodology as in Shetland have been proven to be highly repeatable. One such example is the Woodland Survey of Great Britain, carried out in 1971 and again in 2001. In the repeat survey, the field surveyor relied only on the marked point on a map as the sole aid to relocating the 1971 plot location (as would be the case in a repeat survey of Shetland). Consequently, there is the potential for considerable relocation error. The expectation is that, having made an effort to move near to the mapped point, the plot records from the repeat survey will, on average, be more similar to the respective 1971 plot record than if a completely new, random set of locations were chosen. Even if vegetation change occurs, species compositional data recorded from the same point at times 1 and 2 will tend to be more similar than data recorded from two random points at times 1 and 2. In attempting to measure the amount of relocation error, one cannot of course exploit a "true" set of temporal pairs known to have been recorded in exactly the same position. What can be done is to compare the average species compositional similarity between the ostensibly true temporal pairs with the average similarity for a random pairing of the 1971 data with the 2001 data. If, on average, attempts to relocate the true 1971 position had been successful, then the similarity between the true pairs should be greater than the random pairs. Overall, at 97 of the woodland sites (out of 103), mean similarity was greater between "relocated" plot pairs compared to random-pair comparison; for 59 sites the difference was significantly greater - therefore we were satisfied that the relocation error was not significant when interpreting any results. A full account of this is given in Appendix 3 of Kirby et al. (2005).

\section{Analysis to date}

Aside from the initial analyses undertaken in the final report in 1975, little analysis has been undertaken using the data since, largely due to the authors' other commitments and the inaccessibility of the data set to other workers. The analyses undertaken to date are described in the following subsections. 
Table 4. List of the 25 most abundant species recorded in the survey.

\begin{tabular}{llr}
\hline & Species & Total records \\
\hline 1 & Hypnum cupressiforme & 741 \\
2 & Calluna vulgaris & 740 \\
3 & Potentilla erecta & 699 \\
4 & Dicranum scoparium & 681 \\
5 & Carex panicea & 648 \\
6 & Nardus stricta & 638 \\
7 & Rhytidiadelphus loreus & 608 \\
8 & Cladonia impexa & 607 \\
9 & Juncus squarrosus & 601 \\
10 & Sphagnum rubellum & 598 \\
11 & Eriophorum angustifolium & 596 \\
12 & Cladonia uncialis & 550 \\
13 & Rhacomitrium lanuginosum & 547 \\
14 & Scapania sp. & 542 \\
15 & Agrostis canina & 536 \\
16 & Luzula multiflora & 535 \\
17 & Trichophorum caespitosum & 525 \\
18 & Empetrum nigrum & 507 \\
19 & Hylocomium splendens & 487 \\
20 & Mnium hornum & 482 \\
21 & Anthoxanthum odoratum & 447 \\
22 & Festuca vivipara & 434 \\
23 & Erica tetralix & 433 \\
24 & Agrostis tenuis & 433 \\
25 & Campylopus flexuosus & 431 \\
\hline & &
\end{tabular}

\subsection{Vegetation survey}

The frequencies of species found in the survey confirm much of what has been written about the phyto-geography of the islands, in that the majority of the species are wide-ranging members of heath and bog communities throughout Scotland. The arctic-alpine species present in Shetland are of restricted distribution. However, those that are present often (atypically) extend to sea level. The dominant species found in the survey are typical of the northern habitats of Britain. Along with several species of mosses, Calluna vulgaris had the highest frequency, followed by Potentilla erecta, Carex panicea, Nardus stricta and Juncus squarrosus (Table 4). (Nomenclature follows that of Clapham et al., 1952, as used at the time of the survey.)

In the original survey report (Bunce, 1975), indicator species analysis (ISA) (Hill et al., 1975) (now TWINSPAN) (Hill and Šmilauer, 2005) was used to classify the species lists into 32 classes. The first division was on the basis of heathland species such as Empetrum nigrum as opposed to grassland species such as Holcus lanatus. Subsequent divisions separated classes such as the serpentine grasslands and different types of blanket bogs.

Species groups were constructed from the vegetation data and were designed to help explain details of the structure of the vegetation in Shetland. The groups differed widely from those in Britain and reflect the unique nature of the vegetation of the islands. Details are given in the full report with a discussion of their characteristics (Bunce, 1975). Detailed descriptions of the vegetation classes are included, including the most frequent and dominant species.

The majority of the vegetation is associated with blanket peat, which also intergrades with acid grassland. Agricultural grasslands and serpentine grassland diverge as separate groups. Surprisingly, only two groups are directly controlled by management - peat cutting and burning; the reminder are controlled by environmental factors.

In the 1975 report (Bunce, 1975), the principal axes of variation in the vegetation were correlated with those of the environment using orthogonal regression. The primary axes were correlated with an $r$ value of 0.877 , showing that the main gradients are highly correlated. The first axis of the environment is from acid blanket bogs to fertile grasslands, which compares with a gradient of wet peat soils of low $\mathrm{pH}$ as compared with mineral moist soils of relatively high $\mathrm{pH}$. The factors that limit peat formation are the relatively nutrient-rich bed rocks, the maritime influence and good drainage. All the fertile soils have been used for agriculture, which has increased inputs such as fertiliser and manure adding to the fertility and further divergence from the peatlands. Further detailed discussion is available in the report (Bunce, 1975), but the conclusion is that, with such high correlation, there would have to be major changes in nutrient inputs to deflect the status of a given patch of vegetation in the short term. However, if agricultural inputs had declined to a major degree in the 40 years since the survey, it would be expected that there would be a shift towards more acidic soil conditions.

\subsection{Resource assessment}

As the relationship between the vegetation plots and the environmental land classes is known, the coverage of the plot types throughout the islands may be calculated. The 32 plot types described above were grouped into convenient classes and key species identified as follows, presented with an overall estimate of the percentage of the islands covered:

Calluna/Eriophorum 37.1\%, Calluna/Nardus $23.3 \%$, Nardus $12.7 \%$, Juncus effusus $11.2 \%$,

Calluna/Rhacomitrium 3.0\%, Festuca rubra $4.4 \%$, Agrostis/Holcus $8.3 \%$.

This analysis was the first of its type where cover was calculated from a statistical sample and shows the dominance of bog and heathland vegetation in the islands. By performing analysis in this way, maps may be produced to show the distribution of different vegetation types, an example of which is shown in Fig. 7, showing the estimated distribution of the Calluna/Eriophorum group. The basics of this type of analy- 


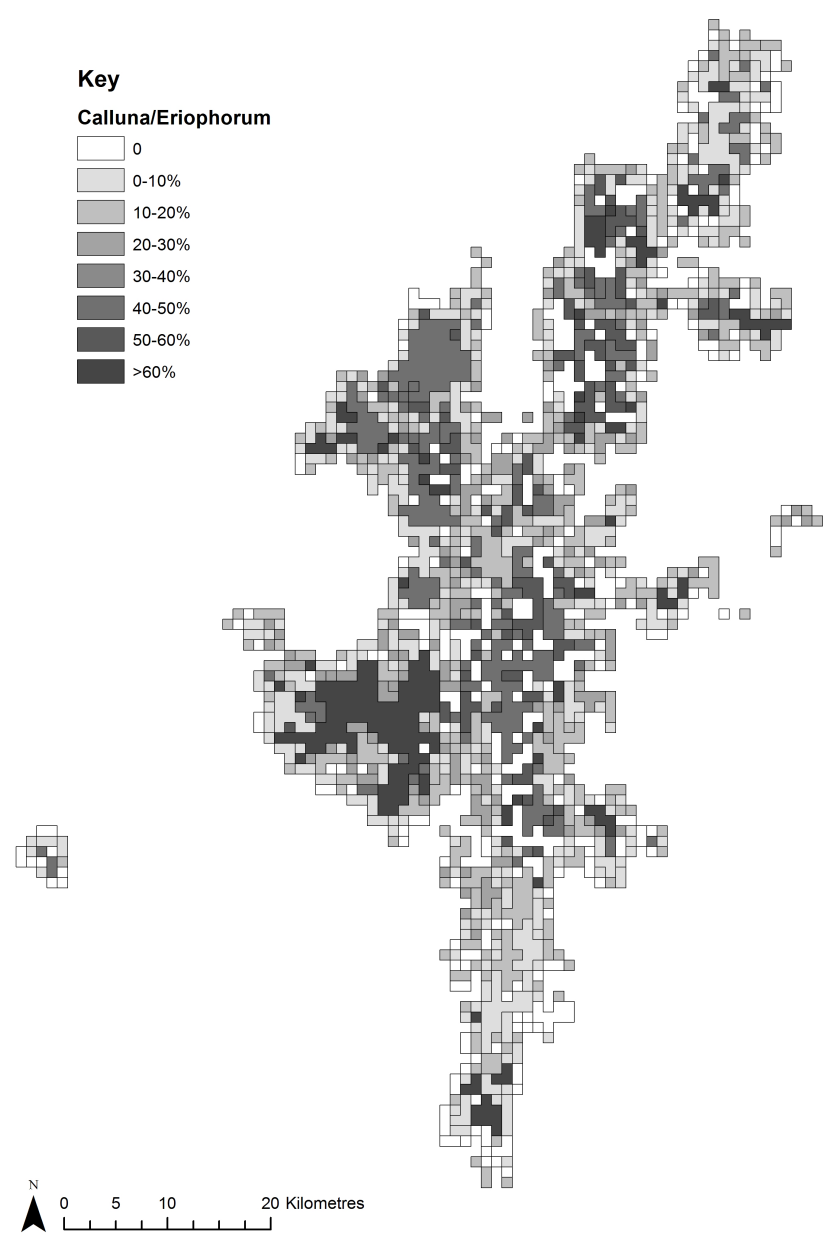

Figure 7. Estimated distribution of the Calluna/Eriophorum group.

sis later came to form the basis of calculations of the national estimates of broad habitats (Jackson, 2000) in Britain, as calculated from Countryside Survey data (Scott, 2008; Barr et al., 2014a, b; Bunce et al., 2012; Brown et al., 2014).

\section{Methodology as a framework for long-term monitoring}

The survey methods were based on those first successfully developed for surveying woodlands across Great Britain (Wood et al., 2015; Bunce and Shaw, 1973). Whereas that survey had focused on woodland sites, the Shetland survey was the first time that samples were being used to obtain an integrated assessment of the response of vegetation to the environment across a defined population across a whole landscape and range of habitats. It was the first project to complete all the stages of land classification, survey, statistical analysis of vegetation and environment through to the estimation of the extent and distribution of ecological resources. The structure of the project provided the basis for the further development of strategic survey methods. The methods de- veloped throughout the 1970s and continued to be tested on a regional basis, as in the Cumbria Survey (Bunce and Smith, 1978).

Although the Shetland survey took place over 40 years ago, the basic methodology has come to underpin much larger and more significant surveys across the whole of Great Britain. The $1 \mathrm{~km}$ square unit sampled at random, with random plots sampled within, became a standard sampling strategy, variations of which are currently used very successfully in several large ecological surveys in Britain, such as the Countryside Survey (Carey et al., 2008) and the Glastir Monitoring and Evaluation Programme (Emmett and GMEP team, 2014). In these surveys, the methods are now implemented very successfully using handheld computers to assist recording the field data and global positioning systems to record the location of the vegetation plots. The development of geographical information systems has greatly facilitated the types of analyses able to be undertaken using this kind of data, and has enhanced the use of the capturing ancillary explanatory data sets, as described in the Integrated Assessment Report for the Countryside Survey (Smart et al., 2010). Outwith the UK, within the European Biodiversity Observation Network (EBONE), methods adapted from the basic principles of the Bunce and Shaw methods have been developed to roll out across the whole of Europe (Bunce et al., 2011, 2008). During the EBONE project, the methods were widely tested across 12 European countries, and also Israel, Australia and South Africa. The methods were proven to be robust, reliable and repeatable at a continental, landscape scale (Roche and Geijzendorffer, 2013).

The repeatability of the methods has been proven in large surveys such as the Woodland Survey of 1971, repeated in 2001 (Wood et al., 2015), and the Countryside Survey (CS) of 1978, repeated in 1990, 2000 and 2007 (Carey et al., 2008; Norton et al., 2012; Sheail and Bunce, 2003). The plots from both of those surveys were sufficiently accurately marked on 1:10000 maps in order to relocate the plot again accurately, as discussed in Sect. 6. Changes in vegetation have been monitored in Britain at roughly 10-year intervals since 1978 via the CS, demonstrating the robustness of the procedure. The major difference between the Shetland Survey and the CS being that $16\left(200 \mathrm{~m}^{2}\right)$ plots were surveyed in each kilometre square on Shetland, whereas only 5 (of that size) were used in the CS, partly because of the experience gained in Shetland, and partly due to the time considerations in surveying the whole country. In the CS, although there are fewer plots $\left(5 \times 200 \mathrm{~m}^{2}\right.$ plots $)$, a habitat mapping component has been introduced, whereby areas of broad and priority habitats (Jackson, 2000) are mapped across each $1 \mathrm{~km}^{2}$, giving the ability to estimate the overall stock of these habitats across the country. Additional smaller plots are also recorded (Maskell et al., 2008a). In Shetland, as in the individual woodlands of the Great Britain Woodland Survey (Kirby et al., 2005; Wood et al., 2015), the data from the 16 plots are relied upon to describe the overall population. 
There are many successful environmental monitoring programmes in Britain (for example the Environmental Change Network, UK Environmental Change Network, 2015; the National Soil Inventory, Cranfield University, 2015; the UK Forest Inventory, Forestry Commission, 2013), Europe (for example Long Term Ecological Research (LTER) programmes; Parr et al., 2003) and worldwide (for example Global Earth Observation System of Systems; Lautenbacher, 2006). All of these have their own merits; however, many programmes have a narrow focus, and most have different measurement protocols and sampling designs (Parr et al., 2002). More recently, a consideration of habitat monitoring in Europe by Lengyel et al. (2008a) highlights several factors that would be desirable when planning monitoring schemes but which are factors often lacking. In particular, spatial variations are barely monitored in over half of the monitoring schemes in Europe, schemes pre-1990 are rare, and few schemes use advanced statistical methods to present the data. In terms of the Shetland survey, spatial variation is a key factor in the design of the survey; the survey is historically significant, being first undertaken in 1974; and the data have been collected in such a way that advanced statistical methods can be applied effectively.

When considering the integration of monitoring programmes across geopolitical zones, issues remain such as the ability to aggregate data across scales, the consistent monitoring of global biodiversity change, and linking of in situ and earth observations (Metzger et al., 2013a). The underlying principles of the Shetland/CS methodology provide an ideal framework for the planning of large-scale monitoring, not only in Britain but also across Europe and worldwide. Metzger et al. (2013a) describe how the idea of environmental stratification as a basis for environmental survey would be ideal to start addressing some of these issues. Indeed, stratifications of Europe and the world have already been produced (Metzger et al., 2005, 2013b). The integration of surveys across Europe is discussed in Lengyel et al. (2008b), who recommend methodology such as BioHab (Bunce et al., 2005) in order to increase the potential for integration. By using the general habitat categories described in Bunce et al. (2005, 2008), data from this Shetland survey could be analysed in a European context and could enhance the understanding of landscape ecological change, in terms of a range of drivers.

\section{Conclusions}

Considering the increased popularity in tourism and the high profile of Shetland in national news since the oil industry arrived, it is surprising that there has been little interest in the overall vegetation for the last 30 years, considering the expansion of ecological research. In addition to being a key milestone in the development of methodology for largerscale monitoring programmes such as the British Country- side Survey (Carey et al., 2008) and the Welsh Glastir Monitoring and Evaluation Programme (Emmett and GMEP team, 2014), the 1974 Shetland Survey data provide a unique baseline from which changes in the vegetation could be determined from repeated locations. A repeat survey or monitoring programme based on the framework described in the present paper would not only yield important scientific results but, when interpreted using the modern procedures developed in Countryside Survey, could also be converted into policy-relevant conclusions and would add considerable value to the existing data sets. The methodology has been shown to be robust and has been used in the CS to follow changes over 30 years. CS has had considerable impact in shaping government policy in biodiversity, particularly in the realm of hedgerow legislation (Barr and Gillespie, 2000; Petit et al., 2003; Anonymous, 1997). None of this would have been achieved had the methodology not been grounded on a sound statistical base.

Within the CS project, changes taking place in the character of the vegetation can be detected, as well as their underlying causal factors. In Shetland, there are a range of factors which could have had an impact on the vegetation in the last 40 years. These include fluctuations in sheep numbers, which affect grazing intensity, and therefore vegetation composition; a decline in traditional crofting, with a possible associated loss in key habitats and species; heathland improvement schemes; peat cutting, which can damage the surface of blanket bog at intense levels; wind farm construction, which can potentially alter an area's microclimate and therefore vegetation; and also sulfur deposition from local shipping and oil deposition, particularly that spilled from the Braer oil tanker, which ran aground off Shetland in 1993.

In the event of a repeat survey, it would be possible to investigate any potential effects of climate change. Since the 1970 s, there appears to be a trend towards higher average temperatures and wetter winters in Shetland. Monitoring the sensitive arctic-alpine species found at unusually low elevations in Shetland could serve as an early warning of the effects of climate change in a global context. The analysis of the wide range of plant types surveyed could also potentially provide information on the effects of any climate changes.

A key benefit of the repeatable methodology described is that it gives an unbiased assessment of change, as shown in the case of the CS and Woodland Survey. A repeat survey of Shetland would provide objective information about the extent of the changes in vegetation since 1974. Results from the repeat surveys and analysis of vegetation changes from the Countryside Survey (Carey et al., 2008) and the British Woodland Survey (Wood et al., 2015; Kirby et al., 2005) have both shown unexpected results that would not have been revealed, had these objective methods not been used. 


\section{Data availability}

The data sets have been assigned digital object identifiers and users of the data must reference the data as follows:

Bunce, R. G. H., Bassett, P. A., and Wood, C. M.: Terrestrial habitat, vegetation and soil data from Shetland, 1974, NERC Environmental Information Data Centre, doi:10.5285/06fc0b8c-cc4a-4ea8-b4be-f8bd7ee25342,

2015.

Bunce, R. G. H. and Bassett, P. A.: Land Classification of Shetland 1974, NERC Environmental Information Data Centre, doi:10.5285/f1b3179e-b446-473d-a5fb4166668da146, 2015.

Both of the data sets are available from the $\mathrm{CEH}$ Environmental Information Data Centre Gateway (https://gateway.ceh.ac.uk) and via the following links: https://catalogue.ceh.ac.uk/ documents/f1b3179e-b446-473d-a5fb-4166668da146, https:/catalogue.ceh.ac.uk/documents/ 06fc0b8c-cc4a-4ea8-b4be-f8bd7ee25342.

Data sets are provided under the terms of the Open Government Licence (http://eidchub.ceh.ac.uk/ administration-folder/tools/ceh-standard-licence-texts/ ceh-open-government-licence/plain, http://www. nationalarchives.gov.uk/doc/open-government-licence/ version/3/)

The metadata are stored in the ISO 19115 (2003) schema (International Organization for Standardization, 2015) in the UK Gemini 2.1 profile (UK GEMINI, 2015). Users of the data sets will find the following documents useful: Shetland Vegetation Survey Handbook of Field Methods (Bunce, 1974) and "Report to NCC on some aspects of the ecology of Shetland. Part III: The Terrestrial Survey of Shetland" (Bunce, 1975).

Author contributions. C. M. Wood prepared the manuscript with significant contributions from R. G. H. Bunce, and is the current database manager for the Land Use Research Group at CEH Lancaster. R. G. H. Bunce designed the experiment (along with M. W. Shaw) and ran the survey in 1974.

Acknowledgements. We thank the land owners and agents who gave permission to conduct surveys on their land. Without their cooperation this project would not have been possible. We also thank the field surveyors: R. G. H. Bunce, P. Bassett, S. K. Morrell, J. Heap, J. B. Hambrey, J. Caird, J. Mackintosh, P. Bibby, M. Ferguson, M. Sturges, D. Thomas, J. Thomas, J. Wilson, P. Swain, M. Horner. Thanks also go to P. Harvey from the Shetland Amenity Trust for providing current background information regarding Shetland, to C. Hallam for entering data, and to F. Huettman and the two anonymous referees, whose comments have improved the manuscript considerably.

Edited by: F. Huettmann
References

Allot, G.: A report on the lowland vegetation of Foula, Brathay Exploration Group Field Studies Report, 11, 48-57, 1971.

Anonymous: The Hedgerows Regulations, The Stationery Office, London, 16 pp., 1997.

Barkham, J. P.: A report on the upland vegetation of Foula, Brathay Exploration Group Field Studies Report, 11, 25-47, 1971.

Barr, C. J. and Gillespie, M. K.: Estimating hedgerow length and pattern characteristics in Great Britain using Countryside Survey data, J. Environ. Manage., 60, 23-32, doi:10.1006/jema.2000.0359, 2000.

Barr, C. J., Bunce, R. G. H., Clarke, R. T., Gillespie, M. K., Hallam, C. J., Howard, D. C., Maskell, L. C., Ness, M. J., Norton, L. R., Scott, R. J., Scott, W. A., Smart, S. M., Stuart, R. C., Wood, C. M., and Wright, S. M.: Countryside Survey 1990 estimates of Broad Habitat areas in Great Britain, NERC Environmental Information Data Centre, doi:10.5285/32dda22c-24cc-4fa8-adcb5481b1b77ef1, 2014a.

Barr, C. J., Bunce, R. G. H., Clarke, R. T., Gillespie, M. K., Howard, D. C., Maskell, L. C., Norton, L. R., Scott, R. J., Scott, W. A., Smart, S. M., Stuart, R. C., Watkins, J. W., Wood, C. M., and Wright, S. M.: Countryside Survey 1998 estimates of Broad Habitat areas in Great Britain, NERC Environmental Information Data Centre, doi:10.5285/ad7babc3-6b43-4754-8981edcf03769f11, 2014b.

Benefield, C. B. and Bunce, R. G. H.: A preliminary visual presentation of land classes in Britain, Institute of Terrestrial Ecology, Grange over Sands, 39 pp., 1982.

Berry, R. J. and Johnston, J. L.: The natural history of Shetland, Collins, London, 1980.

Birse, E. L.: Bioclimatic characteristics of Shetland, in: The Natural Environment of Shetland, edited by: Goodier, R., NCC, Edinburgh, 24-32, 1974.

Blockeel, T. L., Bosanquet, S. D., Hill, M., and Preston, C. D.: Atlas of British \& Irish Bryophytes, Pisces Publications, Newbury, 2014.

British Geological Survey: Quarter-inch geological map of Scotland HMSO, Director General of the Ordnance Survey, Chessington, Surrey, 1963.

Brown, M. J., Bunce, R. G. H., Carey, P. D., Chandler, K., Crowe, A., Maskell, L. C., Norton, L. R., Scott, R. J., Scott, W. A., Smart, S. M., Stuart, R. C., Wood, C. M., and Wright, S. M.: Countryside Survey 2007 estimates of Broad Habitat areas in Great Britain, NERC Environmental Information Data Centre, doi:10.5285/f03cba75-8bca-4679-ae2a-77a9fcbd4df3, 2014.

Bunce, R. G. H.: Shetland Vegetation Survey Handbook of Field Methods, Institute of Terrestrial Ecology, Grange over Sands, 28 pp., 1974.

Bunce, R. G. H.: Report to NCC on some aspects of the ecology of Shetland. Part III: The Terrestrial Survey of Shetland, Institute of Terrestrial Ecology, Grange over Sands, 1975.

Bunce, R. G. H. and Shaw, M. W.: A standardised method for ecological survey, J. Environ. Manage., 1, 239-258, 1973.

Bunce, R. G. H. and Smith, R. S.: An ecological survey of Cumbria, Structure Plan Working Paper, 4, Cumbria County Council and Lake District Special Planning Board, Kendal, 1978.

Bunce, R. G. H., Barr, C. J., Clarke, R. T., Howard, D. C., and Lane, A. M. J.: ITE land classification of Great Britain 1990, NERC 
Environmental Information Data Centre, doi:10.5285/ab320e08faf5-48e1-9ec9-77a213d2907f, 1990.

Bunce, R. G. H., Barr, C. J., Clarke, R. T., Howard, D. C., and Lane, A. M. J.: ITE Merlewood Land Classification of Great Britain, J. Biogeogr., 23, 625-634, 1996a.

Bunce, R. G. H., Barr, C. J., Clarke, R. T., Howard, D. C., and Lane, A. M. J.: Land classification for strategic ecological survey, J. Environ. Manage., 47, 37-60, doi:10.1006/jema.1996.0034, 1996b.

Bunce, R. G. H., Barr, C. J., Clarke, R. T., Howard, D., and Lane, A. M. J.: ITE Land Classification of Great Britain 1998, NERC Environmental Information Data Centre, doi:10.5285/971671a698b4-4d80-b165-21dace7373b9, 1998.

Bunce, R. G. H., Groom, G. B., Jongman, R. H. G., PadoaSchioppa, E., Howard, D. C., and Petit, S.: Handbook for surveillance and monitoring of European Habitats. First edition, edited by: Bunce, R. G. H., Groom, G. B., Jongman, R. H. G., and Padoa-Schioppa, E., Wageningen, Alterra (Alterra report 1219), 107 pp., 2005.

Bunce, R. G. H., Barr, C. J., Clarke, R. T., Howard, D., and Scott, A.: ITE Land Classification of Great Britain 2007, NERC Environmental Information Data Centre, doi:10.5285/5f0605e4-aa2a48ab-b47c-bf5510823e8f, 2007.

Bunce, R. G. H., Metzger, M. J., Jongman, R. H. G., Brandt, J., de Blust, G., Elena-Rossello, R., Groom, G. B., Halada, L., Hofer, G., Howard, D. C., Kovář, P., Mücher, C. A., Padoa-Schioppa, E., Paelinx, D., Palo, A., Perez-Soba, M., Ramos, I. L., Roche, P., Skånes, H., and Wrbka, T.: A standardized procedure for surveillance and monitoring European habitats and provision of spatial data, Landsc. Ecol., 23, 11-25, doi:10.1007/s10980-007-9173-8, 2008.

Bunce, R. G. H., Bogers, M., and Roche, P.: Manual for habitat and vegetation surveillance and monitoring: temperate, mediterranean and desert biomes, Alterra, Wageningen, 2011.

Bunce, R. G. H., Wood, C. M., Henrys, P. A., Smart, S. M., Howard, D. C., and Barr, C. J.: Countryside Survey 1978 estimates of Broad Habitat areas in Great Britain, NERC Environmental Information Data Centre, doi:10.5285/c8feabac-7c3f-4c35-91f7296782b957d1, 2012.

Bunce, R. G. H. and Bassett, P. A.: Land Classification of Shetland 1974, NERC Environmental Information Data Centre, doi:10.5285/f1b3179e-b446-473d-a5fb-4166668da146, 2015.

Bunce, R. G. H., Bassett, P. A., and Wood, C. M.: Terrestrial habitat, vegetation and soil data from Shetland, 1974, NERC Environmental Information Data Centre, doi:10.5285/06fc0b8c-cc4a4ea8-b4be-f8bd7ee25342, 2015.

Carey, P. D., Wallis, S., Chamberlain, P. M., Cooper, A., Emmett, B. A., Maskell, L. C., McCann, T., Murphy, J., Norton, L. R., Reynolds, B., Scott, W. A., Simpson, I. C., Smart, S. M., and Ullyett, J. M.: Countryside Survey: UK Results from 2007, NERC/Centre for Ecology \& Hydrology, Lancaster, 2008.

Chambers, N., Simmons, C., and Wackernagel, M.: Sharing nature's interest: ecological footprints as an indicator of sustainability, Routledge, Oxford \& New York, 2014.

Clapham, A. R., Tutin, T. G., and Warburg, E. F.: Flora of the British Isles, Cambridge University Press, Cambridge, 1952.

Cranfield University: National Soils Inventory, available at: http: //www.landis.org.uk/about/index.cfm, last access: 2 September 2015 .
Czech, B.: Technological progress and biodiversity conservation: a dollar spent, a dollar burned, Conserv. Biol., 17, 1455-1457, 2003.

Dalby, D. H. and Dalby, C.: Shetland Lichens, Shetland Amenity Trust, Lerwick, 2005.

Daly, H. E. and Farley, J.: Ecological economics: principles and applications, Island Press, 2011.

Emmett, B. E. and GMEP team: Glastir Monitoring \& Evaluation Programme, First Year Annual Report to Welsh Government (Contract reference: C147/2010/11), NERC/Centre for Ecology \& Hydrology, Bangor, 442, 2014.

Forestry Commission: National Forest Inventory, available at: http://www.forestry.gov.uk/website/forestry.nsf/byunique/ infd-89s91s, last access: 15 January 2013.

Goode, D.: The flora and vegetation of Shetland, in: The Natural Environment of Shetland, edited by: Goodier, R., NCC, Edinburgh, 50-72, 1974.

Grabherr, G., Gottfried, M., and Pauli, H.: Climate change impacts in alpine environments, Geography Compass, 4, 11331153, doi:10.1111/j.1749-8198.2010.00356.x, 2010.

Hill, M. and Paton, J.: The Bryophytes of Shetland., Nature Conservancy Council/Institute of Terrestrial Ecology, Bangor, 1976.

Hill, M. O.: Reciprocal averaging: an eigenvector method of ordination, The J. Ecol., 61, 237-249, doi:10.2307/2258931, 1973.

Hill, M. O. and Šmilauer, P.: TWINSPAN for Windows version 2.3, Centre for Ecology and Hydrology, University of South Bohemia, Wallingford, 2005.

Hill, M. O., Bunce, R. G. H., and Shaw, M. W.: Indicator species analysis, a divisive polythetic method of classification, and its application to a survey of native pinewoods in Scotland, J. Ecol., 63, 597-613, doi:10.2307/2258738, 1975.

Hill, M. O., Preston, C. D., and Smith, A. J. E.: Atlas of the bryophytes of Britain and Ireland, Harley books, Colchester, 1991.

Huettmann, F.: An Oceanography Conservation View of Central America: Caribbean Wealth, Pacific Wilderness, Plunder and Mismanagement Meets Seafloor Mining, Deep-Sea Drilling, Climate Change, and Human Population Explosion in the EEZs and Beyond, in: Central American Biodiversity: Conservation, Ecology, and a Sustainable Future, edited by: Huettmann, F., Springer New York, New York, NY, 135-158, 2015.

International Organization for Standardization: ISO 19115 (2003), available at: http://www.iso.org/iso/catalogue_detail.htm? csnumber $=26020$, last access: 12 October 2015.

Jackson, D.: Guidance on the Interpretation of the Biodiversity Broad Habitat Classification (Terrestrial and Freshwater Types): Definitions and the Relationship with Other Habitat Classifications (JNCC Report, No. 307), JNCC, 73 pp., 2000.

Johnston, J. L.: A naturalist's Shetland, T. and A.D. Poyser, London, 1999.

Kirby, K. J., Smart, S. M., Black, H. I. J., Bunce, R. G. H., Corney, P. M., and Smithers, R. J.: Long term ecological change in British woodland (1971-2001), A re-survey and analysis of change based on the 103 sites in the Nature Conservancy "Bunce 1971" woodland survey, Final report, Peterborough: English Nature (English Nature Research Reports Number 653), $139+$ appendices, 2005 . 
Lautenbacher, C. C.: The Global Earth Observation System of Systems: Science Serving Society, Space Policy, 22, 8-11, doi:10.1016/j.spacepol.2005.12.004, 2006.

Lengyel, S., Déri, E., Varga, Z., Horváth, R., Tóthmérész, B., Henry, P.-Y., Kobler, A., Kutnar, L., Babij, V., and Seliškar, A.: Habitat monitoring in Europe: a description of current practices, Biodivers. Conserv., 17, 3327-3339, doi:10.1007/s10531-008-93953, 2008a.

Lengyel, S., Kobler, A., Kutnar, L., Framstad, E., Henry, P.-Y., Babij, V., Gruber, B., Schmeller, D., and Henle, K.: A review and a framework for the integration of biodiversity monitoring at the habitat level, Biodivers. Conserv., 17, 3341-3356, doi:10.1007/s10531-008-9359-7, 2008b.

Maskell, L. C., Norton, L. R., Smart, S. M., Scott, R., Carey, P. D., Murphy, J., Chamberlain, P. M., Wood, C. M., Bunce, R. G. H., and Barr, C. J.: Vegetation Plots Handbook CS Technical Report No.2/07, Centre for Ecology and Hydrology, Lancaster, 2008a.

Maskell, L. C., Norton, L. R., Smart, S. M., Carey, P. D., Murphy, J., Chamberlain, P. M., Wood, C. M., Bunce, R. G. H., and Barr, C. J.: Countryside Survey. Field Mapping Handbook CS Technical Report No.1/07, Centre for Ecology and Hydrology, Lancaster, 2008b.

McVean, D. N. and Ratcliffe, D. A.: Plant communities of the Scottish Highlands, A study of Scottish mountain, moorland and forest vegetation, Monographs of the Nature Conservancy, HMSO, London, 445 pp., 1962.

Met Office: UK climate - Historic station data (Lerwick), available at: http://www.metoffice.gov.uk/pub/data/weather/uk/climate/ stationdata/lerwickdata.txt, last access: 1 September 2015.

Metzger, M. J., Bunce, R. G. H., Jongman, R. H. G., Mücher, C. A., and Watkins, J. W.: A climatic stratification of the environment of Europe, Global Ecol. Biogeogr., 14, 549-563, doi:10.1111/j.1466-822X.2005.00190.x, 2005.

Metzger, M., Bunce, R., Leemans, R., and Viner, D.: Projected environmental shifts under climate change: European trends and regional impacts, Environ. Conserv., 35, 64-75, doi:10.1017/S0376892908004529, 2008.

Metzger, M. J., Brus, D. J., Bunce, R. G. H., Carey, P. D., Gonçalves, J., Honrado, J. P., Jongman, R. H. G., Trabucco, A., and Zomer, R.: Environmental stratifications as the basis for national, European and global ecological monitoring, Ecol. Indic., 33, 26-35, doi:10.1016/j.ecolind.2012.11.009, 2013a.

Metzger, M. J., Bunce, R. G. H., Jongman, R. H. G., Sayre, R., Trabucco, A., and Zomer, R.: A high-resolution bioclimate map of the world: a unifying framework for global biodiversity research and monitoring, Global Ecol. Biogeogr., 22, 630-638, doi:10.1111/geb.12022, 2013b.

Milner, C.: Shetland project monitoring report Nature Conservancy Council, Contract Report to the Nature Conservancy Council, 1975.

Norton, L. R., Maskell, L. C., Smart, S. S., Dunbar, M. J., Emmett, B. A., Carey, P. D., Williams, P., Crowe, A., Chandler, K., Scott, W. A., and Wood, C. M.: Measuring stock and change in the GB countryside for policy: key findings and developments from the Countryside Survey 2007 field survey, J. Environ. Manage., 113, 117-127, doi:10.1016/j.jenvman.2012.07.030, 2012.

Ott, R.: Sound truth and corporate myth\$: the legacy of the Exxon Valdez oil spill, Dragonfly Sisters Press, Cordova, 2005.
Parr, T., Ferretti, M., Simpson, I., Forsius, M., and Kovacs-Lang, E.: Towards a long-term integrated monitoring programme in Europe: network design in theory and practice, Environ. Monit. Assess., 78, 253-290, 2002.

Parr, T. W., Sier, A. R. J., Battarbee, R. W., Mackay, A., and Burgess, J.: Detecting environmental change: science and society - perspectives on long-term research and monitoring in the 21st century, Sci. Total Environ., 310, 1-8, doi:10.1016/S00489697(03)00257-2, 2003.

Petit, S., Stuart, R., Gillespie, M., and Barr, C.: Field boundaries in Great Britain: stock and change between 1984, 1990 and 1998, J. Environ. Manage., 67, 229-238, doi:10.1016/S03014797(02)00176-7, 2003.

Preston, C. D., Pearman, D. A., and Dines, T. D.: New atlas of the British and Irish flora, An atlas of the vascular plants of Britain, Ireland, the Isle of Man and the Channel Islands, Oxford University Press, Oxford, 2002.

Roche, P. and Geijzendorffer, I.: EBONE: integrated figures of habitat and biodiversity indicators: quantifying indicators of an integrated biodiversity observation system, Alterra, Wageningen UR, 2013.

Roper-Lindsay, J. and Say, A.: Plant communities of the Shetland Islands, J. Ecol., 74, 1013-1030, doi:10.2307/2260230, 1986.

Scott, W. and Palmer, R.: The flowering plants and ferns of the Shetland Islands, Lerwick: Shetland Times Ltd ix, 468p.-col. illus., maps., ISBN 900662565, 1987.

Scott, W. A.: Countryside Survey. Statistical Report (Countryside Survey Technical Report No. 4/07), NERC Centre for Ecology and Hydrology Lancaster, 2008.

Scottish Government: Scottish Agricultural Census, available at: http://www.gov.scot/Topics/Statistics/Browse/ Agriculture-Fisheries/PubScottishCensus, last access: 7 January 2016.

Scottish Natural Heritage: Shetland, Scottish Natural Heritage, Perth, 2002.

Scottish Rural Development Programme: What Can SRDP Do For Crofting And Small Units?, available at: http://www.crofting.scotland.gov.uk/userfiles/documents/ SRDP\%20paper\%20final.pdf, last access: 7 January 2016.

Sheail, J. and Bunce, R. G. H.: The development and scientific principles of an environmental classification for strategic ecological survey in the United Kingdom, Environ. Conserv., 30, 147-159, doi:10.1017/S0376892903000134, 2003.

Smart, S., Maskell, L., Dunbar, M., Emmett, B., Marks, S., Norton, L., Rose, P., and Simpson, I.: An Integrated Assessment of Countryside Survey data to investigate Ecosystem Services in Great Britain, Countryside Survey Technical Report No. 10/07, NERC Centre for Ecology and Hydrology, Lancaster, 2010.

Spence, D. H. N.: Subarctic debris and scrub vegetation in Shetland, in: The Natural Environment of Shetland, edited by: Goodier, R., NCC, Edinburgh, 50-72, 1974.

UK Environmental Change Network: UK Environmental Change Network, available at: http://www.ecn.ac.uk/, last access: 2 September 2015.

UK GEMINI: UK GEMINI, available at: http://www.agi.org.uk/ join-us/agi-groups/standards-committee/uk-gemini, last access: 12 May 2015. 
Viking Energy: The Project (The Viking Wind Farm), available at: http://www.vikingenergy.co.uk/the-project, last access: 7 January 2016.

Wills, J.: A place in the Sun: Shetland and Oil-Myths and Realities, Mainstream Publishing Company, Edinburgh, 1991.

Wilson, E.: Freedom and loss in a human landscape: Multinational oil exploitation and the survival of reindeer herding in north-eastern Sakhalin, the Russian Far East, Sibirica, 3, 21-48, doi:10.1080/1361736032000168012, 2003.
Wood, C. M., Smart, S. M., and Bunce, R. G. H.: Woodland Survey of Great Britain 1971-2001, Earth Syst. Sci. Data, 7, 203-214, doi:10.5194/essd-7-203-2015, 2015. 